\title{
An Introduction to Petty Bag Proceedings in the Reign of Elizabeth $\mathrm{I}^{\dagger}$
}

\author{
W. J. Jones*
}

F very Lawyer is made to understand that the legal rules and instituE tions of the Middle Ages were radically different from those of modern times. There is no gainsaying that there are differences between the rules and institutions of William I and those of Elizabeth II, or even the conventions and practices of Edward IV and those of George III. The existence of sharp differences between the close of the so-called medieval period and the Hanoverian century, however, has too often been taken as evidence of the existence of similarly sharp differences at various points along the line. For instance, there still seems to be an impression in some quarters that somewhere between the accession of Henry VII in 1485 and the death of his granddaughter, Ehzabeth I, in 1603, such pervasive changes took place in the legal institutions of England as to enable its legal history to be cleaved into distinct eras, the older shrouded in the darkness of "absolutism," the newer bathed in the sunshine of an emerging if embattled constitutionalism. Just as no history would be accepted that implied American legal institutions of 1776 were unrecognizably different from those of 1866, so there should be hesitation in accepting a similar thesis regarding the institutions of the Tudors and the Stuarts. Such a thesis, however, is part of the burden imposed by what was once the traditional concept of the period.

The Whig historians, seeking after the event to explam or justify the constitutional arrangements of 1641,1660 , and 1689, perpetuated the notion of a magical division in the legal scholarship of the 19th Century and hence into the lore of many 20 th Century lawyers. The supposed division was illustrated, one might even say created, by contrasting implicitly the jurisdiction and procedure of the Court of Star Chamber, about which little or nothing was actually known, with an inventive, indeed fanciful, conception of the jurisdiction and procedure of the courts of common law. Odd incidents, called to mind by their notoriety rather than by their typicality or even accuracy, were dragged out of context and, in isolation, dra-

†I am indebted to Professor Geoffrey C. Hazard, Jr., for his helpful comments and suggestions.

* B.A., 1954, London University; Ph.D., 1958, London University; Assistant Professor of History, University of Alberta. 
matized. Such, for example, were the attacks on the ex officio oath, by which the commissioners of ecclesiastical causes conducted investigations, and those on the use of injunctions in certain cases by the courts of Chancery and Requests. Myths concerning the Tudor and early Stuart courts, developed in response to 18th Century political necessities, were thus transformed into assumptions of fact, progressively becoming more irrefutable. In short, scholars were contented for too long to build upon the accounts and assumptions of 18th Century legal and constitutional polemicists. Generally speaking, there has until recently been no systematic attempt to research the 16th Century records of the law courts to discover exactly what they did and how they interacted. That is why it can be said that the study of legal history of Tudor-Stuart times is in its infancy, and that is why it lags behind work done on the political, social, and economic aspects of that intricate period. This statement is made with some trepidation, because one cannot forget the names of Holdsworth, Maitland, and others who have written of those times. Even so it must be said that Holdsworth's massive history ${ }^{1}$ was inevitably limited by the sources available to the author and by the enormous dimensions of the task he undertook. Maitland's writing on the 16th Century is no less brilliant than his work on earlier periods, but his almost instimctive flair does not, it must be said, carry him securely past the Reformation. ${ }^{2}$ Until recently, no one has penetrated the mass of primary documents, often mouldy and imperfect, that reveal the day to day operations of the Tudor and Stuart courts. Over the last decade, however, a great amount of work has been done by scholars and one of the most exciting prospects for the future lies in the continued publication of their conclusions. The cumulative effect may represent a major revolution not only in the historical appraisal of the 16th and 17th Centuries, but also in our general view of the broad flow of Enghish legal history.

Many accounts of purely mechanical developments will have to be written before the legal imstitutions of this particular period are fully understood, but pending the completion of that task, we need not suspend all historical judgments. It is well to put into place in the historical edifice of that era one of those bricks whose outlines may now be perceived. Such is the purpose of this study. Its subject is the jurisdiction and procedure of the Petty Bag-the common law side of the Court of Chancery in the 16th Century.

1 HolDSWORTH, A History OF THE ENGLISH LAW (7th ed. 1956).

2See MAITLAND, Outlines of English Legal History, 560-1600, in 2 THE Coldected PAPERS of Frederick Williasir Matiland 417-96 (Fisher ed. 1911), and the classic if erroneous argument put forth in MaItLAND, EngitsH LAW AND tHE RENAISSANCE (1901). 


\section{INTRODUCTION TO TFE PETTY BAG}

It has long been known that for a period extending through the 17th Century, the Court of Chancery, in addition to its better known and perhaps better understood equity jurisdiction, exercised a common law jurisdiction. The proceedings on this "law side" of Chancery were largely the responsibility of the Petty Bag and its clerical staff. The Petty Bag office has received some comment from historians interested in the later Middle Ages, but its subsequent development in Tudor and early Stuart times has generally been relegated to parenthesis and footnote. ${ }^{3}$

Our ignorance of the Petty Bag is scarcely surprising in view of the paucity of secondary evidence, the uncertainties of contemporaries, and the unattractive nature of the surviving, but incomplete, records. Yet the common law court in Chancery had its own peculiar place in the legal firmament of the 16th Century. In that forum were entertained actions by and against Chancery officials, an instance of the jurisdictional privilege of using their own courts that medieval bureaucrats typically enjoyed; actions upon various kinds of recorded bonds, proceedings not materially different from similar actions maintainable in other common law courts; and proceedings whereby the subject might seek a remedy by petition against his sovereign. In volume and in importance, the inatters in the Petty Bag could not compare with those embraced in the Lord Chancellor's equity jurisdiction, but the Petty Bag was nevertheless quite busy until the second half of the 17th Century when it appears to have experienced a fairly drastic declime in importance. The abolition of military tenures at the time of the Restoration symbolizes the cessation of one branch of its business; certainly it looked increasingly insignificant as litigation swelled

3 For the 15th Century, Pike demonstrated that, in some cases at least, matters which might be expected to belong to the Chancery's extraordinary jurisdiction were handled in a procedure closely analogous to that of the common law and vice versa. Pike, Common Law and Conscience in the Ancient Court of Chancery, 1 L.Q. REV. 443 (1885). Pike's pioncer work was substantially augmented by Hargreaves. Hargreaves, Equity and the Latin Side of Chancery, 68 L.Q. REv. 481 (1952). Standard histories of Englisb law and equity have made a noble attempt to say something about this court, but bave often lacked the raw material on which to build and to criticize. Holdsworth's brief account provides some basic information relevant to the 16th Century, I HondsworTE, op. cit. supra note 1, at 452-53, and the comments made by Dr. G. R. Elton are valuable. Elton, THE Tudor Constitution 151 n.2 (1960). Among earlier writers, Constable and Staunford provide an interesting insight but they were largely concerned with the King's prerogatives. Constabie, Prerogativa Regrs (Thorne ed. 1949); Staunford, An Exposition of the King's Prerogattve (1590). The procedure and jurisdiction of the Petty Bag was but one theme in their closely-worded structures, and did not therefore enjoy suitable elaboration. Useful details can also be culled from the works of Lambarde, West, and Coke. LAMBarde, ARcheion (McIlwain \& Ward eds. 1957) ; WeST, SYMBoleography (1632); 4 Coke, Fourth INSTitute OF THE Laws OF Eivgland 79-80 (1817). 
in other courts. When Blackstone wrote, the importance of Petty Bag had so far declined that he could observe how little was "usually done" on the common law side of Chancery. ${ }^{4}$

In the 16th Century, the Petty Bag handled a great variety of administrative work, which included the issuance of writs for parliamentary elections, writs for the elections of archbishops and bishops, summonses to Parliament, and letters patent of appointment for a number of officials. The office was operated by three clerks, who were appointed by the Master of the Rolls and wrote in his name. Performance of the duties of these clerks was known to require a high śtandard of ability. From at least 1572 until 1593, the same three clerks-Jerome Hawley, George Garth, and Edmund Standen-were in charge, an unbroken tenure of service which doubtless helped to create a tradition of uniformity in the handling of business. In 1593, Sir Edward Norris took the place of Hawley but worked through a deputy, another of those increasingly frequent occasions in which administrative office became a reward for one incapable of discharging the work. There was no restriction on the number of underclerks at this time, but no more than three for each of the three principal clerks seem to have been employed. Although the three Petty Bag clerks were privileged to sit within the bar, it is probable that they were not of ten within court. Their specific tasks with respect to the common law jurisdiction included the supervision and custody of the records and the making out of demurrers.

Most of the legal, as opposed to the administrative, work on the common law side of Chancery was handled by the Six Clerks who fulfilled the function in Chancery of attorneys, and who were responsible for most of the administrative duties on the equity side. The Petty Bag clerks were evidently lax in their paper work and, early in the 17th Century, were accused of losing and failing to file documents. It must be renembered, however, that they did most of their work in the vicinity of the Rolls House, off Chancery Lane, whereas the court of Chancery actually sat in Westminster Hall. Between these two places, a distance of more than a mile, was a network of busy streets, and this separation must surely account for many of the delays that afflicted both the common law and the equity sides of Chancery. Although there are sufficient indications of disorder to suggest. that the Petty Bag department was typical of the period, some of the available evidence appears to suggest that it was comparatively well run. ${ }^{5}$

43 Blackstone, Conarentaries *48.

58 Parltamentary Papers pt. I, 8-13 (1830-1831) ; 1 Sanders, The Orders of the High Court of Chancery pt. I, 3,nn.10-12, 18 (1845); Public Record Office, London, Petty Bag Account Book [hereinafter referred to as P.R.O. Account Book], C220/8 no. 1; British Museum Lansdowne Manuscript [hereinafter referred to as Lansdowne MS.], 163, ff. 120-21, 260-64; Bodleian Library, Oxford, Rawlinson Manuscript, 471, f. 40v. 
In 1598 , a commission of inquiry into the unauthorized raising of fees investigated the operations of the Chancery clerks on both the law and equity sides. Although it provides useful information on Chancery proper, the return of the commission tells little about the administration of the Petty Bag. The clerks of this department, like other senior officials, were represented on the commission and they made the returns for their own office. Few criticisms were made and the truth was not always adhered to. In at least one instance, they quoted a figure that was less than the fee actually being charged, but that was higher than the "traditional" rate." One's appraisal of the morality of this behavior must be conditioned by the recollection that our notions of official morality were not theirs. Furthermore, it is impossible not to sympathize in sone degree with officials, such as those in the Petty Bag, wlo were trying to keep pace with rising prices by raising their fees, the only recognized source of compensation for the performance of their duties. Nevertheless, it is only too evident that expensive duplication and elenientary extortion were pernianent attributes of the system. The public, as often as not, saw it only in this light. This was particularly true of litigants who had to pay for work, such as keeping the entry book up to date, wlich was of no apparent lielp to them but was vital to the court. Furthermore, one rule applied here as to all Elizabethan and early Stuart departments: if no fee was received there was no official responsibility and possibly no official action. Documents could gather dust for years on the floors of offices where they had been thrown, because no one had any interest in picking then up.?

\section{II}

\section{PROCEDURES, AND RELATIONS WITH OTHER COURTS}

Before going into details of the Petty Bag jurisdiction, it may be useful to sketcli briefly some general differences between the procedures normally applicable on the equity and common law sides of Chancery. The equity side employed written pleadings, by this tinıe in English. The most striking features of equity were the sumnions of the defendant by subpoena, his answer and possible exanimation on oath, and the rendition of judgment on both the facts and the law. On the common law side, lowever, proceedings typically commenced by writ. Anıong the writs initiating proceedings, scire facias deserves special mention. The plaintiff would put in a declaration or statement of his claims, to whicl the defendant would have

68 Paritamentary Papers pt. I, 8-13 (1830-1831).

7 Henry E. Huntington Library, San Marino, California, Bridgewater and Ellesmere Manuscript [hereinafter referred to as Huntington Library MS., EI.], 2915, 2918, 2922, 2963, 3001. 
to plead. This might be followed by reply and rejoinder. Pleadings would be terminated either by demurrer or by a conclusion on the facts with trial of the issue by jury. This accords with the general procedure in common law courts.

Considerable difficulty is encountered, however, in ascertaming the procedure for resolving the issues of law and fact raised in Petty Bag proceedings, and this difficulty draws into question the relation of the common law jurisdiction of Chancery to the other courts of the common law. There can be little doubt that, during the period under review, a demurrer was heard and judged in Chancery by the Lord Chancellor, frequently assisted by the judges of the common law courts. When there was an issue of fact, the record was transferred into the King's Beach for trial, there being no jury in Chancery. But where was judgment to be given? Once they began to think of it as a problein, contemporary lawyers found themselves at a loss to reconcile conflicting opinions. The evidence seems to suggest that, at least until the final years of the 16th Century, the most usual practice was for judgment to be given in Chancery. West, whose treatise may be described as eminently practical, was quite clear that after the jury had spoken the record should be remanded back into Chancery for judgment. ${ }^{8}$ Coke seems to confirm this opinion. ${ }^{9}$ The King's Bench judges, however, in Jefferson v. Morton \& Dawson, ${ }^{10}$ found Coke's account uncertain. They differentiated between cases in which a demurrer had been interposed and ruled on in Chancery before the record was sent to the King's Bench, and those in which it had not been ruled upon. They agreed that after the issue was tried in the King's Bench, the record could not be sent back for a ruhing on the previously interposed demurrer. Judgment was given on the demurrer. Chancery, it was pointed out, could have given such a judgment before the record had been sent into the King's Bench. ${ }^{11}$ In other cases a similar opinion was given. ${ }^{12}$ This seems to have been a correct exposition of the existing practice in Chancery.

That King's Bench had authority to give judgment on the issue after trial by jury is indicated by a number of precedents available fron the early years of James $I^{13}$ Furthermore, a case of 1586 , later cited by Lord

82 West, op. cit. supra note 3 , at 177 .

${ }^{9}$ CokE, op. cit. supra note 3 , at 80 .

102 Saund. 22, 85 Eng. Rep. 575 (1669-1670).

11 Id. at 25-28, 85 Eng. Rep. 576-78. Here it is asserted that Coke's authorities do not warrant his opinion.

121 Gen. Abr. Cas. Eq. 128, 21 Eng. Rep. 933-34, where it was concluded that judgment ought to be in Chancery, but, looking back over 17th Century precedents, asked whether the "constant practice" had not been to give judgment in the King's Bench. THE Practice of tire High COURT OF CHANCERY UNFOLded 94 (1651) states that judgment is in the King's Bench.

13 Some of these are cited in Jefferson v. Morton \& Dawson, 2 Saund. 22, 85 Eng. Rep. 575 (1669-1670). 
Nottingham, ${ }^{14}$ and another case reported by Croke for the last year of Elizabeth's reign, ${ }^{15}$ clearly state that judgments on the scire facias had been given in the King's Bench. This also was asserted to be the proper procedure in some 17th Century documents preserved in the British $\mathrm{Mu}$ seum and in the Cambridge University Library, ${ }^{16}$ and by Blackstone. ${ }^{17}$ Even so, no water-tight conclusion can now be drawn. The matter was vexingly uncertain to contemporary lawyers. As already indicated, it appears that for much of the 16th Century the common practice was for judgment on the demurrer to be given in Chancery, subject to determination of the factual issues in the King's Bench. It may well be that when judgments were first and occasionally given in the King's Bench no one thought very much about it. The situation would be more irritating were it not so apparent that this was not the only question to baffle contemporaries, who often were unable to discover a strict rule by examining cases. ${ }^{18}$

The available facts and the nature of the suits handled support strongly the inference that the Petty Bag grew out of the Chancery's administrative work. Even if this is accepted, it is still, as Plucknett has pointed out, "a difficult question how far the common law jurisdiction was an origin of the equitable jurisdiction, which may have had, in the main, a different history."18 At what point the two became distinct is equally unclear, but Holdsworth concluded that after the 15th Century "the procedure upon the ordinary or common law or Latin side of the Chancery, and the procedure upon the extraordinary or equitable or English side, was clearly marked."20 Doubtless this is largely true, albeit a certain element of confusion appears to have persisted with regard to several points. For example, Staunford was uncertain whether the strictness of rules of pleading at common law applied to cases remitted froin the common law side of Chancery for trial in the King's Bench. He cited conflicting opinions from the reign of Edward IV. Some judges had held that a bad traverse was conclusive against

142 Lord Nottrighaar's Chancerv Cases 792 (Seldon Soc'y Pub. 1961).

15 Molineux v. Lacon, 3 Cro. Jac. 12, 79 Eng. Rep. 11 (1602).

16 British Museum Egerton Manuscript [hereinafter referred to as Egerton MS.], 2254, f. 76; Cambridge University Library MS., Gg. 2/31, f. 381 .

173 BLAcKstone, op. cit. supra note 4 , at $* 49$. This view is supported by A Hrstonx of Chancery 5 (1726). The opposing opinion is given in 1 Jacob's Law Dictionary (1st Ain. ed. 1811) under the subtitle "Chancery," but Jacob's wording no less than his authority suggests that his inspiration was drawn from Coke.

18 For instance, no one knew with any certainty where error should lie with respect to these proceedings. There was probably little opportunity to have the question resolved. While some said that Parliament was the proper forum, others asserted that writ of error lay to the King's Bench-an opinion that was to be rebutted in 1682. 1 HocDswortr, op. cit. stipra note 1 , at 452 n.1; cf. 1 Gen. Abr. Cas. Eq. 129, 21 Eng. Rep. 934.

19 PLUCKNett, A Concise History of the Comamon Law 165 (1956).

201 HoLDSWORTH, op. cit. supra note 1 , at 450 . 
the traverser; ${ }^{21}$ others maintained that this was not so because Chancery was a court of conscience. Staunford's own opinion was that since a traverse would conie before the Chancellor by virtue of his ordinary powernot his extraordinary power-the "rigidity" of the common law must be followed. He indicated, however, that this view was fairly questionable. ${ }^{22}$

A recognized distinction between the common law and equity sides of Chancery evidently existed even though it was not always so clear. For instance, Chancery as a court of equity was nornally open irrespective of the vacations, whereas the common law courts were tied to the ternis. Nonetheless, Lambard thought that the Lord Chancellor could hold pleas in his common law jurisdiction "at all times, as well within the term as after."23 In all probability this may have been true for much of the 16th Century. A late Elizabethan case, however, established the contrary. Judgment had been entered on the last day of the term, but on the following day it was stayed by a warrant signed by Lord Keeper Egerton. The Attorney General protested that the Lord Keeper's ordinary authority with such proceedings at the common law was limited to the terni, and therefore he could not stay judgment in such a fashion. Egerton accepted this argunent, but the interesting point is that he should have been uncertain -or professed to have been so-about his authority. ${ }^{24}$

By the end of the 16th Century, there seeins to have been a general understanding that if matters of conscience arose on the ordinary side, the Lord Chancellor was competent to judge only according to common law. If conscience were vitally involved, then the defendant ought to exhibit a bill and so commence proceedings on the equity side. One debtor, bound in a recognisance for fifty pounds, exhibited such a bill and deposited one hundred pounds with the court as security for his good intentions. It was held that there was no further cause for proceedings to continue on the common law side. In other words, a bill in equity was held to have precedence over the common law form of action. ${ }^{25}$

At times it is difficult to extricate Petty Bag proceedings from equity causes. From the entries in the register books, it is obvious that points arising from the common law jurisdiction would be discussed and ruled upon in open court. The common law cases would often be dealt with at random among those grounded upon equity. Procedural points and hearings would

21 A traverse in this sense was simply the defendant's denial of nuatters of fact put forward in the plaintiff's pleadings or declaration. On this denial a good issue could be made up.

22 Cited by Pike, supra note 3 , at 454 .

${ }^{23}$ LAMBARDE, op. cit. supra note 3 , at 33 .

24 Egerton MS., 2254, f. 95v.

25 British Museunı Additional MS., 48056, pp. 95-96; Public Record Office Register (Entry) Book of Decrees and Orders [hereinafter referred as to P.R.O. Register Book], C33/85 f. 61, Courtney v. Robinson (1592). 
likewise be handled at the Rolls, already in extensive use to relieve the burden of hearings at Westminster Hall. For example, in a suit for repeal of letters patent, which had issued to Sir John Perrot and which allowed him to purchase lands belonging to a school, the cause was ordered to be heard at the Rolls before Sir William Cordell, Master of the Rolls, together with the Chief Justice of the Common Pleas and Mr. Justice Weston. If they wished they could remit the whole matter over to the Exchequer Chamber. ${ }^{26}$ Other instances of participation by common law judges may be found. In Markeham v. Wyllyams ${ }^{27}$ a demurrer was reached on a point of procedure which was referred to Justices Gawdy and Wyndham. Counsel on both sides were to argue the points and, if the Justices so desired, reduce the problem to a case. The judges gave their opinion but the Solicitor General maintained that it was for Chancery to judge, and he clearly hoped to get some advantage by a formal hearing. He suggested that insofar as usury was surmised-implying, it would seem, that this might temper Chancery's attitude if not that of the Judges-equity was involved. It was ruled that a Master was to take an account of the debt; a day of hearing was fixed and the judges requested to attend. ${ }^{28}$

Pressures on the Lord Chancellor to exercise his equitable authority must have been strong. It may well be that the court sometimes prompted a party to exhibit a bill in equity. Alternatively, if the parties to a suit on the common law side agreed to submit to the arbitration of the Lord Chancellor, this would presumably have freed him from any common law limitations. ${ }^{29}$ It might be expected that as both the common law and equitable procedures of Chancery became increasingly formalized, the distinction between them would become clearer. After all, jurisdictions can best be defined in terms of procedure. Yet, largely because both jurisdictions were vested in the authority of the Lord Chancellor, some minor transference was bound to occur. There are pitfalls in the way of anyone attempting to make a legitimate and firm differentiation between the records of these two jurisdictions, let alone to use the records as a basis for inferring differences in procedure. For the most part, the judge was the same and the court entry book was the same. ${ }^{30}$ Furthermore, the instruments normal to Chancery's

26 P.R.O. Register Book, C33/27 f. 149v., The Queen v. Sir John Perrot (1562); CAL. PATENT Rotis 305 (1558-1560).

27 Markeham v. Wyllyams (1590-1591) as reported in Monro, Acta Cancelcarrae 596, 605-06, 612-13 (1847).

28 Irrespective of the Solicitor General's implication, it was in order for a defendant to use a scire facias on a recognisance to plead the Statute of Usury. Wolfe v. Powell, Choyce Cas. Ch. 119, 21 Eng. Rep. 73 (1578-1579).

29 P.R.O. Register Book, C33/35 f. 37, Eveleigh v. More (1567).

30 The Petty Bag did, however, have its own Remembrance Rolls which provide some, often desiccated, procedural information. 
equity work were often present in a suit on the common law side. There are several illustrations. Written depositions could be taken in Chancery and used as evidence for a trial held in the King's Bench upon a transfer of the case. ${ }^{31}$ An injunction would be issued against any party who commenced suit in some other court over a matter pending in the Petty Bag. ${ }^{32}$ If a judgment had been given, and both parties afterwards agreed to submit to arbitration, that judgment would not be enforced. ${ }^{33}$ Should there be any suspicion of collusion or fraud involved in, or arising out of, a case on the common law side, it would be referred to one of the Masters of Chancery and later discussed in open court. ${ }^{34}$

One reason the procedural mixture occasionally looks peculiar is that, as already emphasized, the same entry book was used for day to day proceedings. More important, however, one must not be carried away by distorted ideas of the functions of 16th Century courts. Chancery, for instance, would use its powers on behalf of suitors litigating in any other court, lay or ecclesiastical, great or small. It would often dismiss causes to such other tribunals, reserving equitable considerations for itself. In such cases, in a single controversy, two quite distinct courts were involved and therefore the procedures were clearly distinct. Yet although the controversy was single, the historian of today may be unable to link up the two suits. Within Chancery, where equity and common law procedures were conducted simultaneously, were entered on one basic record, and were largely determined by one judge, similar practices need occasion no more surprise. Not all of this procedural concurrence was the result of administrative convenience being permitted to cut the corners of procedural regularity; inucl of it was simply an illustration of the broader cooperation that existed between tribunals exercising respectively law and equity jurisdictions.

\section{III}

\section{JURISDICTION}

The jurisdiction of the common law side of Chancery, the actual types of suits entertained, can be roughly divided into five categories. First there were various personal actions brought by or against officials of the court, a privilege which within limitations was possessed by all the major courts. In the second group were proceedings consequent upon recognisances and statutes staple. Third there were petitions to revoke or amend letters

31 P.R.O. Register Book, C33/25 f. 337, Halley v. Goodwin (1562).

32 Id. C33/25 f. 337, The Queen v. Sir John Perrot (1562).

$33 \mathrm{Id}$. C33/41 f. $64 \mathrm{v}$., Broughton v. Viscount Bindon (1570). There was nothing unusual in this nor anything that might be said to be a peculiarity of Chancery alone.

34 Id. C33/60 f. 18, Jefferyes v. Brook (1579). 
patent. A fourth group concerned traverses of inquisitions post mortem. Finally there were such miscellaneous and minor matters as perjury and charitable uses. While these groups are fairly variegated, some connecting features can still be discerned. Recognisances, statutes staple, letters patent and inquisitions post mortem were all documents recorded in Chancery. Petitions arising out of letters patent or inquisitions were similar in that either the sovereign or his grantee were concerned. The procedural vehicle by which the business was conducted was typified by certain writs, such as scire facias to repeal letters patent.

\section{A. Cases Involving Officers of Chancery}

Chancery officials, like the officers and clerks of other courts, were privileged to sue and be sued in their own court. The theory was that such officials, if they were to attend to their duties and to their clients, should be spared attendance in other places. Naturally there were limitations. For example, Masters Extraordinary could not claim the privilege since they were "not bound to any ordinary attendance."35 Furthermore, a claim of privilege was valid only insofar as the particular court was competent to give the appropriate remedy. Thus Chancery privilege did not extend to freehold or felony, but it did cover personal actions, including trespass for debt. $^{36}$ When an officer of Chancery was plaintiff, process commenced with an attachment of privilege directed to the slieriff of the county where the defendant was supposed to be. The sheriff was responsible for seeing that things went smoothly. If, for instance, he returned a cepi corpus-certifying the arrest of the party-but failed, perhaps because of another's blunder, to secure the arrival of the defendant in London, he was liable to pay a fine to the Queen. ${ }^{37}$ The defendant, on arrival in London, would have to act immediately in order to satisfy the requirements of bail, without whicls his appearance could not be entered. ${ }^{38}$

If, on the other hand, the privileged person were the defendant, proceedings might well have been started against him in another court, and if so a supersedeas of privilege would issue against the proceedings. The

35 Drewry v. Plasyer (1587), as reported in MonRo, op. cit. sucpra note 27, at 572 .

36 Jones, Chancery Attitudes in the Reign of Elizabeth I, 5 AM. J. LEGAI. HIST. 12, 13-14 (1961); 1 Gen. Abr. CAS. EQ. 128; Public Record Office, Rolls Chapel Series, C43/8/108.

37 P.R.O. Register Book, C33/60 f. 44, Hambye v. Wryght (1579); id. C33/60 f.112, West v. Saunders (1579).

38 The defendant had to both bind bimself for $£ 400$ and produce four sureties of $£ 100$ each. The sureties were to assure the defendant's daily appearance and were bable to satisfy both damages and costs. This divergence from normal common law practice was objected to, and the Chancery came into line with other courts in 1654. 1 SANDERs, op. cit. supra note 5, at 57-58, 266. However, it was possible for the defendant to be licensed to depart once he had put in bail and answered the plaintiff's declaration. Carew v. Burfam, Cary 106, 21 Eng. Rep. 56 (1578-1579). 
proper procedure was for the plaintiff to file his declaration in the Petty Bag, leaving the defendant to take notice of it at his peril. No process was served, on the theory that officials were always present and by construction of law, if not by fact, it was assumed that the defendant was already in court. If he failed to plead by the end of the term, he was liable to have judgment entered against him. The usual practice, however, seems to have been that the defendant lost the benefit of his privilege, and the plaintiff was at liberty to seek his remedy elsewhere. ${ }^{30}$ This was something of a handicap to the plaintiff, but perhaps it was not so bad when compared with evasions possible in most procedures of the day. On the whole it may be concluded that there was a general awareness that privilege should not be abused or prevaricated.

A plaintiff would start proceedings by delivering his declaration to his own attorney. The defendant would then be given a "day" - a certain length of time, usually a week - in whicl to answer. The plaintiff's attorney, having signed the declaration, would send it into the Petty Bag and a note would be entered on the remembrance roll. If the defendant failed to plead in time, he was "forejudged the court." 40 The course followed when the privileged person was in default has already been noticed. When the defendant was not privileged, Chancery normally appears to have granted another or peremptory "day." This was usually within the next five weekdays. The defendant's plea would be passed to the opposing attorney. The plaintiff, if he wished to proceed to trial, might join issue and leave it to a jury for determination in the King's Bench. Alternatively, he might reply and leave it to the defendant to join issue within a week. If the defendant did nothing at all, judgment was entered against him by nihil dicit. If, at any permissable stage, the plaintiff or defendant entered a demurrer, it would be argned before the Lord Chancellor. ${ }^{42}$

\section{B. Recognisances and Statutes Staple}

For the Tawney century (1540-1640), studies of merchants and townsfolk, gentry and aristocracy, court and country, have devoted considerable attention to the financial affairs and conditions of the various ranks in society. This was a world which lived on credit but which had few credit institutions. In order to raise money, wealthy men often had to pawn their plate and jewelry, sell their lands or borrow on their expectations-the profits of the harvest, next year's rents, or even inheritance. The creditor needed some form of legally valid acknowledgment to protect his own in-

39 Egerton MS., 2254, ff. 76; Cutts v. Johnson, Choyce Cas. Ch. 164, 21 Eng. Rep. 95 (1582-1583) ; P.R.O. Register Book, C33/31 f. 456v., Croydon v. Donnet (1565).

40 The Practice of the High Court of Chancery Unfolded 93 (1651).

41 Egerton MS., 2254, ff. 75v.-76; The Practice of the High Court of Chancery UnFOLDED 93-96 (1651). 
terests in case of default. Bonds of record, such as recognisances and statutes staple, provided such a protection, and they could be proceeded upon if the loan were not repaid.

The sum mentioned on the face of the bond was the amount that the "debtor" had acknowledged himself hable to pay if he failed to refund the original loan by a certain time. The sum specified represented a penalty, not the aunount of money borrowed. The "debtor" may indeed have promised to return borrowed money, but it is equally probable that he had undertaken some other commitment. For example, a litigant whose attendance was required from day to day in a law court would often be bound in a recognisance to assure his attendance. Likewise, almost any kind of promise or contractual undertaking - to go somewhere, to do something, to sell an article, to share a profit-would probably be secured by some such recorded obligation. ${ }^{42}$ The proceedings to enforce these obligations, in the Petty Bag and elsewhere, technical though they may seem, give a glimpse of a very vital undercurrent of society.

Recognisances and statutes staple constituted judgments that theoretically were as valid as any given in a court of law after formal judicial proceedings. The "debtor" had, by his acknowledgment, admitted the obligation. ${ }^{43}$ Lawyers must have recognized, however, that in reality these were inferior judgnients. Coke was certainly of this opimion and he stressed that a judgment in a court of law "upon [a] judicial and ordinary proceeding

42 Earl of Oxford's Case, 1 Chan. Rep. 1, 13, 21 Eng. Rep. 485, 488 (1615); cf. JAcon, op. cit. supra note 17, and RASTELI, Les Termes de la Ley (1685) (both under the subtitle "Recognisance").

There were many kinds of bonds or obligations, not all of which were entered of record in a court.
A Bill or Obligation (which be all one, saving that when it is in English, it is com- monly called a Bill, and when it is in Latin an Obligation) is a deed, whereby the obligor dotl knowledge himself to owe unto the obligee a certain sum of inoney or other thing. In which besides the parties' names are to be considered, the sum or thing due, and the time, place, and manner of payment, or delivery thereof. Obliga- tions be either by matter in deed or of Record. An Obligation by matter in deed is every obhigation which is not knowledged and made in some court of Record .... 1 WEST, op. cit. sucpra note 3 , at $\S 100$. Bonds or bills entered into by deed, and usually consisting of small pieces of paper whicl could easily be lost or destroyed, occasioned considerable litigation on the equity side of Chancery. But inasmuch as they were not recorded, and hence were not in form judgments, they did not concern Petty Bag.

43 The defendant, or "debtor," could not by normal course of law plead that anything had occurred since the judgment to discharge the execution. Autdita querela filled the gap by allowing a defendant to initiate a saving action to avoid execution. It could, for instance, be used if he were already in prison for another cause, or if it were necessary to avoid a recognisance by claiming the party to have been under age at the time of the acknowledgment. In this case, Clancery would allow the "debtor," now in the position of plaintiff, to examine witnesses to prove his age. The classic example of the law books slows a man and his heir bound in an obligation; the man laving died, the "creditor" recovered from the lieir, and then sued the executors. The executors thereupon took out an audita querela to avoid the clain. The total effect was obviously similar to a suit in equity to prevent the double repayment of a debt. 
is more notorious and conspicuous, and of more high and eminent degree, than a statute or recognisance taken in private . ..."44

Recognisances and statutes staple were formal and intricate. They represent one of the larger segments of litigation occurring on the common law side of Chancery. Some confusion seems to have arisen due to the broad meanings attached to the word "recognisance" by some contemporaries. West, however, distinguished between "mere" recoguisances and the three types of statutes staple. ${ }^{45}$

[A] recognisance is a bond of record testifying the recognisor to owe unto the recognisee a certain sum of money, and is knowledged in some court of record, or before some judge or other officer of such court, having authority to take the same: as the Masters of Chancery, the Judges of either Bench, Barons of the Exchequer, Justices of the Peace, etc. And those that be mere recognisances are not sealed, but are enrolled. And execution by force thereof, is of all the recognisor's goods and chattels, except his draft beasts and implements of husbandry, and the moiety of his lands ....46

\section{A "creditor" wishing to enforce a recognisance taken in the Court of} Chancery could obtain a scire facias from a clerk of the Petty Bag by producing a copy of the overdue bond. ${ }^{47}$ The scire facias having been returned, the plaintiff retained an attorney and a "day" was given to the recognisor

See, e.g., Earl of Oxford's Case, I Chan. Rep. 1, 9, 21 Eng. Rep. 485 (1615); cf. Brooke v. Straker (1594), as reported in Monro, op. cit. supra note 27, at 647; Davy v. Pepys, 2 Plowd. 438, 75 Eng. Rep. 658 (1573). "I tell you plainly," said Stonor, J., "that audita querela is given rather by equity than by common law." Cited in PuUcknexr, op. cit. supra note 19, at 394. Plucknett, pointing out the traditional common law dislike for abuse of its procedure, has noted that not too much should be read into all this, and that Stonor's remark can be construed as meaning no more than that the writ allowed a "debtor" to plead common law defenses of which he was otherwise deprived by statute. Id, at 393-94. Audita querela, by placing the "creditor" in the position of defendant, however, invites comparison with the equity procedure. Holdsworth seems to imply that it had become largely obsolete since its heyday in the 13th Century, 1 HolosworTH, op. cit. supra note 1, at 224-25, but in the Tudor period it was very much ative on the common law side of Chancery. Sir John Puckering, Lord Keeper from 1592 to 1596, attempted to restrict its use by ordering that no such writ was to be used without his knowledge. 1 SANDERS, op. cit. supra note 5, at 65 . With respect to its use in other courts, Ellesinere seems to have had it in mind when he grumbled that "in such Cases the Judges also play the Chancellors." Earl of Oxford's Case, supra at 10-11, 21 Eng. Rep. at 487.

444 Co. Rep. 60a, 76 Eng. Rep. 1022. An outlawry constituted a similar judgment.

451 WeST, op. cit. supra note 3, at \$§ 100-09; Spence, "The Third Earl of Cumberland," London Umiversity $\mathrm{Ph} . \mathrm{D}$. Thesis (1959). No attempt is made here to give a complete picture of all the varieties of procedure.

461 WEST, op. cit. supra note 3 , at $\$ 103$.

47 If a "creditor" wished to enroll a recognisance in Chancery in order to take out a scire facias, he first had to exhihit a bill on the equity side and obtain a subpoena requiring the defendant to show any objections. Sidenham v. Harrison, Cary 97, 21 Eng. Rep. 51 (15791580). By the end of the century, it had been directed that a scire facias was to be refused on recognisances not enrolled in Chancery and on recognisances with antedates. The record was to be examined before any scire facias was issued, even in a legitimate case. 1 SANDERs, op. cit. supra note 5 , at 71 . 
to come in and plead. Subsequent proceedings would be similar to those described for suits of privilege if the recognisor chose to "emparle" and plead. It was specifically established that the plea put in had to be precise and to the point. For instance, it was not sufficient to mention some transaction which had taken place in London without specifying the ward. ${ }^{48}$ If the court required the defendant's plea to be amended and yet this was not done, a nihil dicit might ensue and judgment be entered against him as a matter of course. A demurrer could be made, however, at least in the beginning of Elizabeth's reign, on an insufficient plea and the defendant be compelled to abide by it, provided that it did not give him an unfair advantage. If issue were joined on the facts, the record would, of course, be made up and sent to the King's Bench for trial to a jury. If at the outset the defendant ignored the scire facias and failed to plead, judgment would be entered and execution awarded. The "creditor" could then have a levare facias directing the sheriff to levy the forfeited sum from the recognisor's goods and lands. In addition, he might, according to the circumstances, have a capias for the defendant's apprehension until satisfaction was obtained. Alternatively, if the defendant's goods were insufficient to cover the sum involved, the "creditor" could by elegit take physical possession of half the recognisor's lands until he was satisfied out of the profits. ${ }^{40}$

In cases where the original recognisor had died, the sheriff would answer the scire facias by returning a mortuis. A special scire facias de novo then issued against the heir and terre-tenants-that is those who were in actual possession of the land on the day the recognisance was entered into. The heir himself was counted as a terre-tenant if he were not bound by the recognisance along with his ancestor. In many cases, however, he would have been a party to the original bond and this device would then be unnecessary. Otherwise, the general procedure had to be followed faithfully even though the recognisor's death was an occurrence known to all. On the other hand, if the "creditor" had died his heirs might proceed without undue problems. ${ }^{50}$

The powers of execution attached to statutes staple were more extensive than in the case of "mere" recognisances.

A statute staple properly so called, is a bond of record knowledged before the Mayor of the Staple, in the presence of one of the two Constables of

48 P.R.O. Register Book, C33/60 ff. 343, 375, Tusser v. Saperton (1580).

40 Lansdowne MS., 163, f. 195; P.R.O. Register Book, C33/60 f. 19v., Tybbott v. St. John (1579). In the 17th Century, the practice developed making it possible to take out two scire feci directed to the sheriff of Middlesex, who would return the nihils certifying that the party had not been found.

50 P.R.O. Register Book, C33/60 f. 17v., Fletcher v. Everard (1579); id. C33/60 f. 81, Susan v. Cope (1579); 5-6 JACOB, op. cit. supra note 17, subtitles "Terre-tenant" and "Recognisance." 
the same Staple .... And by virtue of such a statute staple the creditor may forthwith after certificate thereof into the Chancery have execution of the body, lands, and goods of the debtor .... A statute staple improper, is a bond of record founded upon the statute of 23 Henry VIII cap. 6 of the nature of a proper statute staple, as touching the force and execution thereof, and knowledged before one of the Chief Justices and, in their absence, before the Mayor of the Staple and the Recorder of London . . . 51

When a statute staple fell due, the "creditor" would take the original, together with a certificate from the appropriate clerk, to the Clerk of the Crown in Chancery who would provide a writ of extent. This writ empowered the sheriff of the county in which the lands of the "debtor" lay, to empanel a jury to assess both the "debtor's" lands and any chattels that he might be found to have. The sheriff's inquisition having been made and the writ executed, the writ of extent would be returned into the Petty Bag where the clerks would make out a liberate to put the "creditor" in possession of the estate. However, before this became effective, a scire facias had to issue against the defendant and normal proceedings in litigation might follow if the defendant had a defense. If the "debtor" were dead, a liberate would have to be followed by a capias; legal niceties having been quieted, the "creditor" could then have a writ of re-extent. and subsequently a new liberate with all their attendant formalities. When the "debtor" considered that satisfaction had been obtained he would sue out a scire facias ad computandum. This could be a prelude to a whole new set of proceedings, the "debtor" insisting that the debt had been met or even overpaid, the "creditor" perhaps asserting that neither was true. Tudor litigation rarely had a tidy ending. ${ }^{52}$

\section{Letters Patent}

Letters patent-open pieces of parchment with the Great Seal pendant -were the means employed by the Crown in making, for example, grants of lands and office, appointments to commissions, and bestowals of charters to corporations. They were enrolled in Chancery and thus they represent another aspect of the common law jurisdiction of the court. A grant from the Crown was implicit in every letters patent. Revocation or aunendment

51 West, op. cit. supra note $3, \S \S 107,109$. King's Bench and Common Pleas, but not Chancery, were concerned with statutes merchants. It will be noted that unlike "mere" recognisances, statutes were sealed. Staples were towns or places and the body of merchants appoimted by royal authority to have exclusive rights of purchase over particular types of goods. There were staples in many English towns.

62 Pugh, "Provisional Note Upon Recognisances in the Nature of a Statute Staple," Public Record Office Note No. 123; P.R.O. Register Book, C33/85 f. 28v., Palavicino v. Tusser (1592); id. C33/85 f. 59v.-60, Sherrington v. Fulwood (1592); id. C33/60 f. 26, Kelwaye v. Albany (1579); id. C33/60 f. 44, Hambye v. Wryght (1579). 
of letters patent involved a petition to the Sovereign, since only the Crown could rescind its own grant. Therefore, the Crown had to appear in the role of plaintiff and take out the appropriate scire facias.

The case of The Queen $v$. The Leathersellers' Company of London ${ }^{63}$ provides an illustration of the procedures involved. Certain individuals petitioned against the powers of scrutiny and supervision which the Company wielded by authority of letters patent. The Crown in response took out a scire facias against the Company. A declaration upon the writ was filed in the Petty Bag. A procedural point was first dealt with; the Lord Keeper assisted by both Chief Justices, the Chief Baron, and Mr. Justice Periam directed amendment in the scire facias. The defendants then put in their plea, to which the Queen demurred. At first the Company refused to join in this and they were given a "day" to do so at their peril. The Company having complied, the Lord Keeper required counsel on both sides to set down the points of demurrer in order that he might be informed of the arguments. He also asked the two Chief Justices to assist him further. At the hearing, the Chief Justices agreed that the letters patent should be repealed insofar as they either touched rights of view and search or provided for the correction of and punishinent for defects in leather and any other offenses. A "day" was given to the defendants' counsel to show cause why this judgment should not stand, and the order completed with a note of signature. Subsequently, the Lord Keeper directed that judgment was to be entered on the scire facias. The case was concluded within a few months. ${ }^{54}$

63 P.R.O. Register Book, C33/85 ff. 12v., 80v., 91, 120, 176, 183, The Queen v. The Leathersellers' Company of London (1592-1593).

54 P.R.O. Rolls Chapel Series, C43/6/134; The Queen v. The Leathersellers' Company of London, supra note 53. The Leathersellers hitigation provides in brief a good example of the procedure adopted. The case itself was part of a much larger issue of which some notice may be taken. The Leathersellers, like the Haberdashers and other London Companies, had come to be controlled by entrepreneurs who knew comparatively little of the arts involved in lenther manufacture. Craftsmen such as the Glovers resented this control and were encouraged to challenge it by Edward Darcy, a Groom of the Chamber, best known for his later and controversial monopoly of playing cards. In our particular case we have seen that the control exercised by the Company was broken, but it was to be replaced by a grant of roughly similar powers inade to Darcy who promptly opened an office to certify leather and skins. The Company fought him tooth and nail and refused to acknowledge his authority. Four of their Wardens were imprisoned, and an attempt at mediation before the Lord Mayor of London ended in a near riot after Darcy had publicly assaulted an Alderman of the City. In their petitions to the Queen, the Company went so far as to describe one of Darcy's agents as being a descendant on the distaff side of a witch. They were eventually successful in having the grant rescinded. UNWIN, THE GIIDS AND COMPANIES OF LoNDON 256-58 (1908).

No costs were recoverable on a scire facias such as was used in the Leathersellers litigation. Digges v. Palmer, 1 Co. Rep. 157a, 172a, 76 Eng. Rep. 352, 372 (1598-1600). Similar procedures can be seen in the attempt during 1561 and 1562 to repeal letters patent granted to Sir John Perrot. P.R.O. Register Book, C33/25 f. 337, C33/27 ff. 62, 149v. 
Other examples of a scire facias to repeal letters patent are to be found in the Petty Bag. Judgment was given that a grant of the office of bannerbearership of the field made by Queen Mary to Thomas Sulyard should be annulled.55 Municipal privileges, especially with regard to fairs and markets, were often disputed: the rights of Torrington in Devon were challenged ${ }^{56}$ another suit concerned the appomtment of a mayor and the right to hold a fair and market at Thaxted in Essex ${ }^{57}$ in Cornwall, the inhabitants of Dunheved alias Launceston charged that markets and fairs held at the adjoining borough of Newport alias Launceston were detrnnental and without authority. ${ }^{58}$

\section{Traverses of Inquisitions Post Mortem}

The Tudor success in reviving certain feudal incidents provided one of the most vexing social and administrative problems of the hundred and fifty years before the civil war. Anyone who held by the feudal tenure of kmight's service owed a number of incidents to his lord, and Henry VII had finally made certain that the King was once again reestablished as the superior lord. Consequently he had the most to gain from the revitalization of these incidents, or prerogatives as they were called. For example, to receive his lands, an heir had to pay a relief - a monetary fine - and if he were under age, both he and his land were subject to incidents such as wardship and livery. This meant that the King could take possession of the lands until the heir came of age, and then exact a fine before handing over the property out of wardship. Wardships and the marriages of heiresses could be bartered by the Crown for cash. ${ }^{59}$

While the Crown set out to secure as much profit as possible in this way, it was obviously to the tenant's interest to conceal any incidents due to the Crown. Both Chancery and the Court of Wards, set up in 1540 to supervise the Crown's mterests, were concerned with inquisitions post niortem. The purpose of an inquisition, the requisite preliminary to the inheritance of property held by knight's service in chief, was to ascertain the extent of any feudal rights that the Crown might have in the estate of an heir. Inquisitions were normally undertaken by virtue of a writ or commis-

55 P.R.O. Rolls Chapel Series, C43/5/20.

56 Id. C $43 / 5 / 48$.

57 Id. $\mathrm{C} 43 / 5 / 55$.

58 Id. C43/6/39; cf. Sir George Reynel's Case, 9 Co. Rep. 95, 77 Eng. Rep. 871 (1612); The Prince's Case, 8 Co. Rep. 1a, 77 Eng. Rep. 481 (1606); Digges v. Palmer, 1 Co. Rep. 157a, 76 Eng. Rep. 352 (1598-1600).

59 It should perhaps be observed that the revival of feudal incidents although initially of financial advantage to the Tudors became in time less attractive because revenues dwindled to a point where they ceased to be adequate compensation for the resentment and resistance that was excited by the efforts to collect them. 
sion that issued out of Chancery on authority of the Court of Wards. The escheator or commissioners, as the case might be, were thereby empowered to take an office - an inquiry into and a formal recital of lands and tenures -and to return the inquisition to the Petty Bag. In theory the inquisition would subsequently be transcripted into the Exchequer and into the Court of Wards. ${ }^{60}$

On an average, the Petty Bag seems to have acknowledged receipt of approximately two hundred inquisitions post mortem for each year of Elizabeth's reign; 1579 was a peak year with some three hundred inquisitions being returned. ${ }^{61}$ These fignres have a value, however, only insofar as they give an mdication of the amount of work involved. They have little validity for other purposes. Scepticism has always surrounded the value of an inquisition, and criticism could be levelled at almost every aspect of the compilation of these documents; but it was over the process of return into Chancery and subsequent transcription into the Court of Wards that the cumbersome and amateurish Elizabethan system really broke down. Irate officials of the Court of Wards may well have cited a habitual saying, current among Chancery men, to the effect that it was unnecessary to transfer an inquisition which appeared to contain nothing with which a wardship or livery might be maintained. ${ }^{62}$ In practice this attitude sometimes meant that the Court of Wards failed to receive the inquisitions of tenants who had undertaken to conceal incidents from the Crown. Furthermore, in spite of the rules, specific directions, and the actual phrasing of commissions, escheators and others having made an mquisition too often failed to convey the document to London. Sometimes they did not even take the trouble to close it up and seal it. The result was that on many occasions inquisitions were brought open into the Petty Bag by all sorts of carriers, sometimes by the very people who would benefit if any claim on the part of the Crown could be avoided. In short, there was ample opportunity for tampering.

Even if an escheator or commissioner bestirred himself to carry the inquisition to London, a further hurdle presented itself. The clerks of the Petty Bag expected to be paid for making copies and for the work of transferring the record to the Exchequer and Court of Wards before they received and filed any inquisition. No specific provision was made for the

60 The outstanding authorities are BELL, THE COURT OF WARDS and LrVERrEs (1953) and HURSTrieID, THE QUEEN's WARDS (1958). Although the traditional officer in charge of these royal interests was the escheator, the Court of Wards made increasing use-either on commissions or through its own surveys-of the feodary, who Bell describes as "the executive officer of the court in each county."

61 Compiled froun P.R.O. Account Book, C220/8 no. 1 .

63 Huntington Library MS., El 2963. 
payment of these fees and many escheators and commissioners saw no reason why the money should come out of their own pockets. Yet the Petty Bag clerks refused to receive the documents without payment. In many instances, the carriers would throw inquisitions onto the floor of the Petty Bag office, and the clerks would walk about on them or push them aside when free movement became obstructed. Occasionally they would relent and file a few, though they could see no reason for transferring them into any other court. On one occasion, sometime after Sir Thomas Bromley became Lord Chancellor in 1579, officials of the Court of Wards came with authority to collect all unattended inquisitions and to carry them off. In the mid-1590's, there was a strong feeling that another raid was long overdue and, indeed, two expeditions appear to have been made. Successive Masters of the Rolls, Sir Gilbert Gerrard in 1591 and later Sir Thomas Egerton, attempted to solve the problem or at least to prevent further deterioration. Their efforts were apparently attended with little success. In 1598, Edmund Standen, the senior clerk of the Petty Bag, reported to Egerton on the great backlog of unfiled inquisitions in the Petty Bag and bemoaned the "slackness and backwardness" of years.

Assuming that the taking of the office had been regularly completed and the rights of the Crown to incidents established, the office was held to be valid until discharged by proceedings of equal authority. A normal example of such proceedings would be the ritual of suing out livery once a tenant had come of age. There was often an imitial cause for grievance about the rights claimed by the Crown, however, and a remedy could be sought in a number of ways. It was possible to challenge the jury which had made the office. Alternatively, the land which the inquisition had found to be in the hands of someone recently dead might be claimed by a previous tenant or some other person. Here procedure would be by monstrance de droit. In other circumstances, if the Crown had entered upon the land without any color of legality, the aggrieved party had to proceed by petition. ${ }^{64}$

Most important of all, however, was the right to traverse. The word traverse simply signifies the technical device adopted as the vehicle for the proceedings. Writ procedure was unavailable because no writ could lie against the Crown. As a remedy the right to traverse was of considerable potential although the frequency with whicl it was effectively employed has been doubted. Any person grieved, who could claim title to the lands in question, had a right to show that the inquisition was defective or untrue. Yet in what seemingly was the best way of having the findings of an inquisition re-examined and perhaps altered, the cards appear to have been

63 Id. at 2915, 2918, 2922, 2963.

64 BEI, op. cit. supra note 60, at 75-76; HURSTFIET, op. cit. supra note 60, at 45-46. 
stacked against the would-be traverser. It was first necessary to prefer a bill in the Court of Wards in order to obtain a license and decree permitting a traverse. To get this license, it was imperative for the plaintiff to show prima facie evidence of wrong findings and to establish his interest in the matter. Permission to proceed would only be given if the Crown's title were based solely on the inquisition and not on any other record. Once permission was granted, the plaintiff would have to bring the decree into Chancery. Even so, the Attorney of the Court of Wards was sometimes called upon to appear and to confirm that such a license had been granted. The traverser was then required to put in bonds to prosecute his suit, and-a condition likely to discourage any hesitant complainant-to pay costs in the event of the traverse being adjudged against him. When the license had been produced and the bonds entered into, the next stage was to have a plea of traverse drawn up and engrossed in the Petty Bag. All process whereby the Crown might take advantage of the office found was thereupon stayed. ${ }^{\circ 5}$

In response to the traverse thus brought, the Attorney General, on the Queen's behalf, had the advantage of being able to choose between a number of courses. He could confess to the traverse, maintain the Crown's title, or disprove the plaintiff's title. This very element of choice was a factor weighing against the traverser. If the Attorney General confessed, the party had judgment and an ousterlemaine to the effect "that the Queen's majesty's hands shall be moved from the possession" and the traverser restored with full profit. ${ }^{60}$ If the Attorney General decided to plead, as we have observed, he could select whichever course of action seemed easier.

[T] he King hath a prerogative that a common person hath not, for His Highness may choose whether he will maintain the office, or traverse the title of the party, and so take traverse upon traverse, or when all his titles be traversed, His Highness may choose to maintain them all or else but one of them ....67

The Attorney General having elected to plead, issue would be joined and, on the record being made up, the action would be transmitted into the King's Bench for trial. If the traverser won, an ousterlemaine would issue. Even at this stage, the traverser remained in jeopardy that the Crown might find some other basis for claiming rights to the property in question. ${ }^{08} \mathrm{It}$ has been noted that such a claim might have been urged as a ground for

65 P.R.O. Register Book, C33/19 f. 169, Wilks v. Leveson (1559); P.R.O. Rolls Chapel Series, C43/14/3, 4; Lansdowne MS., 163 f. 195.

66 P.R.O. Register Book, C33/33 f. 64v., The Queen v. Hill (1566); id. C33/27 f. 439v., Worseley's Case (1563) ; id. C33/23 f. 275, Bassett's Case (1561) ; P.R.O. Rolls Chapel Series, C43/6/104.

67 Staunford, An ExPosition of the King's Prerogative 65 (1590).

68 Id. at 61 . 
denying permission to proceed with the traverse in the first place. Such a claim on behalf of the Crown would be equally valid after a traverse had been successfully maimtained, "the said traverse and judgment thereupon given in anywise notwithstanding."

Clearly this was a protracted and cumbersome procedure, even when entered into with good cause. "What it amounted to," writes H. E. Bell, "was that the practice of the Court [of Wards] acknowledged, but rather discouraged, traverses." ${ }^{\text {"70 }}$ Indeed, discouraged suitors were only too ready to believe that officialdom was deliberately unfriendly. From here it was but a short step to the strictures of Coke who claimed, as late as 1625, that the Court of Wards in refusing to allow traverses, except by bill, was acting in restraint of the common law. ${ }^{71}$ Yet, in reality, the system may not have been quite as it is sometimes pictured. Dr. G. R. Elton has indicated that during the reign of Henry VII there seems to be almost as much evidence of traverses being conceded as of their being contested. Traversing, he suggests, appears to have been "coinmon and straight-forward."72 Much the same conclusion can be reached for the reign of Elizabeth by which time, if anything, conditions were more favorable to the traverser than had been the case in some earlier years. At least a number of the traverses were conceded, though this is of course an impression gained from partial evidence. Short of painstaking work and an appreciable anount of luck, there seems little likelihood of any definitive evaluation of the usefulness of the traverse in the near future. The solution would seem to lie perhaps not in the percentage of successful traverses but in an assessment of how many people, if any, with a reasonable case were so deterred by the odds that they never made the attempt. ${ }^{73}$

\section{E. Miscellaneous}

The remaining aspects of hitigation in Petty Bag are scarcely comparable with those discussed above. One of these was perjury. During the reign of Elizabeth, perjury was a jurisdiction which existed more in fiction than in fact. Originally, Chancery had taken cognizance of perjury by examin-

694 Statutes of the Realat 48.

70 BELI, op. cit. supra note 60 , at 76 .

71 Ibid.

72 Elton, Henry VII: A Restatement, 4 Hist. J. 7-10 (1961).

73 Remaining among the Petty Bag records are the traverse of an inquisition taken on the fight of William Rastell to Flanders, P.R.O. Rolls Chapel Series, C43/6/3, and another on the supposed death of John Burdett, a soldier presumed killed in the Low Countries but later found to be alive. Id. C43/14/14. It was also possible to traverse the inquisition taken on the estate of an idiot. Id. C43/10/58. On the death of a tenant-in-chief, the widow might have to make an application by writ of right of dower on the common law side of Chancery. Id. C43/5/35; BELI, op. cit. supra note 60 , at 4,85 . 
ing the suspected offender on oath after he had been proceeded against by English bill or affidavit. The statute of 1563 authorized judges to hold jurisdiction over perjury committed by witnesses in their respective courts. ${ }^{74}$ Subsequently, it was held that whereas Star Chamber might proceed by bill, Chancery would have to examine perjurers through proceedings on its common law side. ${ }^{75}$ There is, however, little evidence of such a course being adopted. When defendants on the equity side committed perjury, there was probably ample justification for continuing to maintain bills against them; as to non-party witnesses appearing in suits on the equity side, Lord Chancellors may well have exercised discretion with respect to suspected perjury. At the same time, it was not unknown for such witnesses to be proceeded against in Star Chamber. ${ }^{76}$

Another of the jurisdictional miscellanea concerned charitable bequests. Statutes of $1597^{77}$ and $1601^{78}$ vested authority in the Lord Chancellor and Chancellor of the Duchy of Lancaster to appoint commissions which were to inquire into supposed abuses of charitable bequests and to make any necessary rectification by decree. With regard to Chancery, decrees establishing such bequests would be certified to the Petty Bag. Those on whose instigation the Commission had been appointed could have an attachment with the possibility of further process of contempt against defendants who did not perform a decree. A defendant, or any other interested party, could make a bill of exception to review the decision of the commissioners and have it filed after the attachment had been made out. If the Lord Chancellor rejected the exception outright, the attachment could issue. Otherwise process was stayed. The exception would have to be answered, witnesses examined and the matter heard summarily in open court. The Lord Chancellor might confirm, modify or nullify a decree. He appears to have been allowed full discretion. A bill of exception was not comparable to a normal bill or petition, and this work can scarcely be described as pertaining to Chancery at all but properly belonged to the Lord Chancellor by virtue of statutory authority. Fundamentally, it was administrative convenience which dictated that the machinery of Chancery, in particular that of the Petty Bag office, should be utilized. ${ }^{79}$

745 EIIz. I, c. 9.

75 Dyer 288.

761 Spence, The Equitable Jurisdictịon of the Court of Chancery 691 (1846-1850); P.R.O. Register Book, C33/41 f. 175, Nudigate v. Pledall (1571); id. C33/85 f. 45, Ringwood $\nabla$. Bulkley (1592); Ex Parle Everard (1574), as reported in Monro, op. cil. supra note 27, at 413 .

7739 Exiz. I, c. 6.

7843 EIIZ. I, c. 4.

70 P.R.O. Crown Office Precedent Book, C193/4 ff. 84v.-85; 5 P.R.O. Lists and Indexes, intro; Lansdowne MS., 163 f. 196; Cary 28. 


\section{CONCLUSION}

This has been no more than an introduction to the judicial business associated with the Petty Bag. Quite apart from the Elizabethan era, a great deal more work could still be done on this court, particularly on its origins and decline. The common law side of Chancery had few pretensions, and its jurisdiction was singularly disjointed. Yet trifles did not make up the sum total of its litigation. In the right of traverse and petition to the Sovereign reposed an elementary principle of the English legal system. Proceedings upon recognisances and statutes staple could touch the varied transactions of men in different walks of life. All this may appear somewhat distant, but the common law side of Chancery was geared to the needs of a society considerably removed from more modern times. In the 17 th Century, as military tenures were abolished and penal bonds declined before new methods of credit, the Petty Bag had less and less with which to concern itself. A court which has not the means to adapt itself to changes in society has no alternative but to fade from importance. The Petty Bag, although it hung on, may well be seen as having some affinities with the two great provincial councils of Wales and of the North, which died less because they were objected to than because they were no longer needed to control once-turbulent areas. There is no call to assume that institutions which were abolished, or which tended to wither, were always obnoxious or supernumerary. Lost in the shadows as it may have been, the Petty Bag once filled a very necessary niche. 